<シンポジゥム 09-4＞ヒト中枢神経の functional connectivity の新しい解析法 多次元神経イメージングによる脳内ネットワーク解析

花川隆

\title{
（臨床神経 2010;50:901-902）
}

Key words : 神経回路, 神経機能イメージング, 拡散強調トラクトグラフィー, 神経電気生理, 経頭蓋磁気刺激

神経機能イメージングは, その誕生以来, ことなる機能に特 化した脳領域を分離抽出していくことが「こころ」の機能の理 解につながる，という原理あるいは信念に基づいて発展して きた。この考えは機能分離 (functional segregation)の原理と 呼ばれ，Paul Brocaによる運動性言語中枢の発見以来，多く の損傷研究により支持されている．機能分離の考え方は statistical parametric mapping 法(課題要素の変化に相関して生 じる脳活動の変化を, 画像の撮像単位ごとに統計的に比較し 統計值を画像化する手法) と相性が良く, 脳機能マッピングと 呼ばれる研究領域として神経機能イメージングが普及する上 で大きな支えとなった.しかし最近, 意識や思考など複雑な機 能を担う脳のメカニズムを解明する上で, 神経線維連絡で結 ばれている遠隔脳領域間がどのように情報のやり取りをおこ なっているかを理解することの重要性が再認識されるように なっている. そのため, 脳内神経ネットワークの構造・機能解 析を目的としたイメージング手法が多く提案され始めた。 そ して「多次元神経イメージング」とは, 電磁気生理学計測, 脳 刺激法, 磁気共鳴画像 (MRI) るくし複数の神経イメージン グ法を統合し，大量の同時計測情報をシームレスに扱う計 測・解析プラットフォームを開発する提案である．個々のイ メージング手法が内在する久点を補い，結果の相互検証がで きるため, 信頼性の高い結果がえられると期待される ${ }^{11}$.

多次元神経イメージングによる神経ネットワークイメージ ングとして, 現時点で解剖連関イメージング (anatomical connectivity imaging), 機能連関イメージング (functional connectivity imaging) と誘発連関イメージング (evoked connectivity imaging）を様々な組み合わせでもちいることができ る. 解剖連関イメージングは, 拡散強調 MRI のトラクトグラ フィー解析に基づく. 拡散パラメーターを確率分布関数とし て推定した上でトラクトグラフィーを㧍こなう手法（probabilistic tractography $)^{2}$ や白質構造の新しい標準化法に基づく 解析 (tract-based spatial statistics) ${ }^{3}$ の開発により, 精度の高 い神経ネットワークの描出が可能になってきた. しかし,トラ クトグラフィーを抗こなう際には関心領域を設定する必要が ある.われわれは, 多次元神経イメージング技術の確立に向け た取り組みの一環として, 機能的 MRI や MRI 解剖画像の解 析による voxel-based morphometry（VBM）の結果に基づい
て客観的かつ機能解剖的に関心領域を設定している.

機能連関イメージング手法のうち, 刺激や課題によって生 じる脳領域間の活動の相関や因果関倸の変化を検出する手法 は effective connectivity 法と呼ばれることがある. Psychophysiological interaction (PPI) 法や dynamic causal modeling (DCM) 法など複数の手法が提案されている ${ }^{4}$. これらの手法 をもちいることで, 大脳皮質間の機能連関だけでなく, 小脳と 大脳皮質領域間の機能連関なども描出できるようになっ た ${ }^{5 / 6)}$. また, 安静時に測定した機能的 MRI デー夕の領域間相 関解析により, 脳ネットワーク内では脳活動の自発的変動が 同期 (resting-state connectivity)していることがみいだされ, 注目を集めている7).ただし, resting-state connectivityには 呼吸や脈拍など血管系に生理的に生じている影響の大きさを 指摘する報告も出始めていることから, resting-state connectivity 研究を推進する上でも, 呼吸や脈拍など生理モニタリ ングも取り込む多次元イメージング手法が有用であると思わ れる。

誘発連関イメージングは, 経頭蓋磁気刺激 (TMS) や経頭 蓋直流電気刺激 (tDCS) などの非侵襲脳刺激法, 電気生理測 定と機能的 fMRI を組み合わせ, 脳内ネットワークの描出を おこなう手法である. 脳を刺激すると, 刺激された部位だけで なく, 刺激領域とネットワークを構成している遠隔領域にも シナプス結合を介した神経活動が誘発されると考えられてい る. TMSによる脳刺激と脳活動の同時計測により, 神経ネッ トワークに誘発される脳活動を測定することができる，われ われは, TMS, 筋電図と機能的 MRI の同時測定系を構築し た ${ }^{8}$. 一次運動野に様々な強度の TMS を与えると, 刺激部位 から離れた補足運動野や小脳などにおいても, TMS 強度に対 して非線形的に応答する脳活動が誘発される．閾值上 TMS 刺激のばあいには，運動にともなう筋からの固有感覚入力に より惹起される脳活動が混在する可能性があるため, 正中神 経刺激などの種々の対照条件を加えて同時測定を㧍こなっ た. その結果, 運動にともなう固有感覚入力による脳活動は運 動野ネットワーク内に広く観察された. しかしながら TMS により誘発される脳活動と固有知覚入力によると思われる脳 活動の割合を比較すると, 固有知覚入力の影響は従来考えら れていたよりも小さいことを示した(投稿中)，以上を考え合

国立精神・神経医療研究センター神経研究所〔テ187-8502 東京都小平市小川東町 4-1-1〕

科学技術振興機構さきがけ研究

(受付日：2010 年 5 月 22 日) 
わせると，一次運動野への閾值上 TMS と脳活動の同時計測

系は, 運動ネットワークを描出する方法として有用であると

考えられる。

機能連関, 解剖連関, 誘発連関イメージングをシームレスに 統合する多次元イメージング法は, 将来的には分子イメージ ングや遺伝学イメージング (imaging genetics) を取り込むこ とで, さらに大きく発展することが期待される.

\section{文献}

1) Walsh V, Cowey A. Transcranial magnetic stimulation and cognitive neuroscience. Nat Rev Neurosci 2000;1:7379.

2) Behrens TE, Woolrich MW, Jenkinson M, et al. Characterization and propagation of uncertainty in diffusionweighted MR imaging. Magn Reson Med 2003;50:10771088.

3) Smith SM, Johansen-Berg H, Jenkinson M, et al. Acquisition and voxelwise analysis of multi-subject diffusion data with tract-based spatial statistics. Nat Protoc 2007;2:499503.

4) Friston KJ, Ashburner J, Kiebel SJ, et al, editors. Statistical Parametric Mapping: The Analysis of Functional Brain Images. Academic Press; 2007.

5) Abe M, Hanakawa T, Takayama Y, et al. Functional coupling of human prefrontal and premotor areas during cognitive manipulation. J Neurosci 2007;27:3429-3438.

6) Aso K, Hanakawa T, Aso T, et al. Cerebro-cerebellar interactions underlying temporal information processing. J Cogn Neurosci 2010;22:2913-2925.

7) Fox MD, Raichle ME. Spontaneous fluctuations in brain activity observed with functional magnetic resonance imaging. Nat Rev Neurosci 2007;8:700-711.

8) Hanakawa T, Mima T, Matsumoto R, et al. Stimulusresponse profile during single-pulse transcranial magnetic stimulation to the primary motor cortex. Cereb Cortex 2009;19:2605-2615.

\section{Abstract \\ Multidimensional neuroimaging approach for studying brain network}

Takashi Hanakawa, M.D., Ph.D.

National Institute of Neuroscience, National Center of Neurology and Psychiatry

Precursory Research for Embryonic Science and Technology, Japan Science and Technology Agency

Here we propose multidimensional non-invasive imaging to understand the functional anatomy of neural circuits of the human brain. The multidimensional network imaging technique currently employs anatomical, functional and evoked connectivity imaging in various combinations. The anatomical and functional connectivity imaging can be achieved by the analysis of diffusion-weighted and functional magnetic resonance imaging (fMRI), respectively. New analysis techniques such as probabilistic diffusion tractography and tract-based statistics have refined the anatomical connectivity imaging, especially in combination with fMRI for setting up regions-of-interest. For the evoked connectivity imaging, brain stimulation technique such as transcranical magnetic stimulation (TMS) is performed during acquisition of fMRI and electrophysiology monitoring. Despite technical challenges, it is important to put information from these different modalities for network imaging together for fair understanding of human brain functions.

(Clin Neurol 2010;50:901-902)

Key words: neural circuits, functional neuroimaging, diffusion-based tractography, neuro-electrophysiology, transcranial magnetic stimulation 